\title{
Morphological and geochemical features of crater lakes in Costa Rica: an overview
}

\author{
Franco TASSI*, Orlando VASELLI, Erik FERNANDEZ ${ }^{1)}$, Eliecer DUARTE ${ }^{1)}$, Maria MARTINEZ ${ }^{1)}$, \\ Antonio DELGADO HUERTAS ${ }^{2)}$ and Francesco BERGAMASCHI \\ Department of Earth Sciences, Via G. La Pira 4, 50121, University of Florence (Italy) \\ ${ }^{1)}$ Volcanological and Seismological Observatory, Nacional University, Heredia (Costa Rica) \\ ${ }^{2)}$ Estacion Experimental de Zaidin (CSIC), Prof. Albareda 1, 18008, Granada (Spain) \\ *e-mail corresponding author: franco.tassi@unifi.it
}

\begin{abstract}
This paper describes the compositional and morphological features of the crater lakes found in the volcanoes of Rincón de La Vieja, Poás, Irazú, Congo and Tenorio volcanoes (Costa Rica). As evidenced by the distribution of the water and dissolved gas chemistry along vertical profiles, the different fluid sources feeding the lakes reflect the present status of each of the volcanic systems. The chemical features of the Caliente (Poás volcano) and Rincón crater (Rincón de la Vieja volcano) lakes are mainly dependent on i) inputs of magmatic fluids from sub-lacustrine fumaroles and ii) water-rock interaction processes. Conversely, the Irazu lake is mainly affected by the presence of $\mathrm{CO}_{2}\left(\mathrm{H}_{2} \mathrm{~S}\right)$-rich fluids discharged from a hydrothermal system, which masked possible magmatic fluid contributions. Rainfall and organic activity are the main factors responsible for the chemical composition of Hule, Botos, Congo and Tenorio lakes. The chemical and isotopic water composition of Botos, Irazu and Hule lakes have displayed no significant variations along the vertical profiles. In contrast, Caliente lake shows a distinctive chemical stratification, mainly involving $\mathrm{F}, \mathrm{Cl}^{-}$and $\mathrm{SO}_{4}{ }^{2-}$. The behaviour of these compounds seems to be governed by both dissolution of highly acidic species, i.e. $\mathrm{HF}, \mathrm{HCl}$ and $\mathrm{SO}_{2}$ released from the magmatic environment, and microbial activity. Despite the significant increases with depth of dissolved $\mathrm{CO}_{2}$ at Caliente and Irazu lakes, the hazard for Nyos-type gas eruptions can be considered negligible, since i) the water volumes are too small and ii) the convective heat transfer limits the $\mathrm{CO}_{2}$ recharge rate. The relatively high concentrations of dissolved $\mathrm{CO}_{2}$ measured at the maximum depth of the Hule lake are likely produced by both degradation of organic material and degassing from a deep source. The sporadic episodes of fish deaths recently observed in this lake can be associated with lake overturn processes that have favoured the rise up to the lake surface of deep, oxygen-depleted waters.
\end{abstract}

Key words: lake stratification, limnic eruptions, hyperacidic lake

\section{INTRODUCTION}

Crater lakes represent unique natural systems at the Earth's surface. They are commonly present in volcanic systems characterized by recent activity, being found in more than $12 \%$ of the 714 post-Holocene volcanoes of the world (Simkin et al. 1981). Crater lakes increase volcanic hazard because uprising magmas may directly interact with lake water, leading to high-energy phreatomagmatic eruptions, e.g. Taal volcano, Philippines (Blong 1984). Moreover, the ejected volcanic products displace the lake waters, enhancing the effects of secondary phenomena, such as the lahars, e.g. Mt Ruapehu, New Zealand (Nairn et al. 1979) and Mt Kelut, Indonesia, (Badrudin 1994). Crater lakes hosted within quiescent volcanic systems interact with magmatic-hydrothermal fluids, acting as condensers and calorimeters for acidic volatiles and heat from magmatic degassing (e.g., Brantley et al. 1993; Anzidei et al. 2008). This implies that contributions from sub-lacustrine gas vents, coupled with bacterial activity, may produce large $\mathrm{CO}_{2}\left(\mathrm{CH}_{4}\right)$-rich dissolved gas reservoirs (Martini et al. 1994; Kusakabe 1996; Schmid et al. 2005). Destabilization of stratified layers at depth may cause turnover of the lake (Rice 2000) induced by either heat flux through the system or landslides from the inner crater flanks triggered by heavy rains or seismic events. At the surface, lake turnover produces the so-called "limnic eruptions" (Kusakabe 1996 and references therein), such as those occurred at Lakes Monoun and Nyos (Cameroon) in 1984 and 1986, respectively (Sigurdsson et al. 1987; Evans et al. 1993, 1994). Volcanic lakes affected by hydrothermal /magmatic fluid discharges are frequently dynamic hydrologic systems, and the high secondary permeability of the volcanic sequences greatly enhances fluid circulation (Sanford et al. 1995; Varekamp et al. 2000). Consequently, the physical-chemical characteristics of crater lakes are often useful to monitor and forecast volcanic events in active and dormant systems (Giggenbach 1974, 1983; Rowe et al. 1992; Christenson 2000; Anzidei et al. 2008).

Costa Rica is a land of volcanoes, eight of which are characterized by the presence of crater lakes (Haberyan et al. 2003). There are lakes within i) dormant volcanoes (Congo and Barva volcanoes), ii) systems showing moderate hydrothermal activity (Irazú and Tenorio volcanoes) and iii) craters with strong fumarolic emissions and where periodic phreatic eruptions have recently occurred (Rincón de la Vieja and Poás volcanoes). 


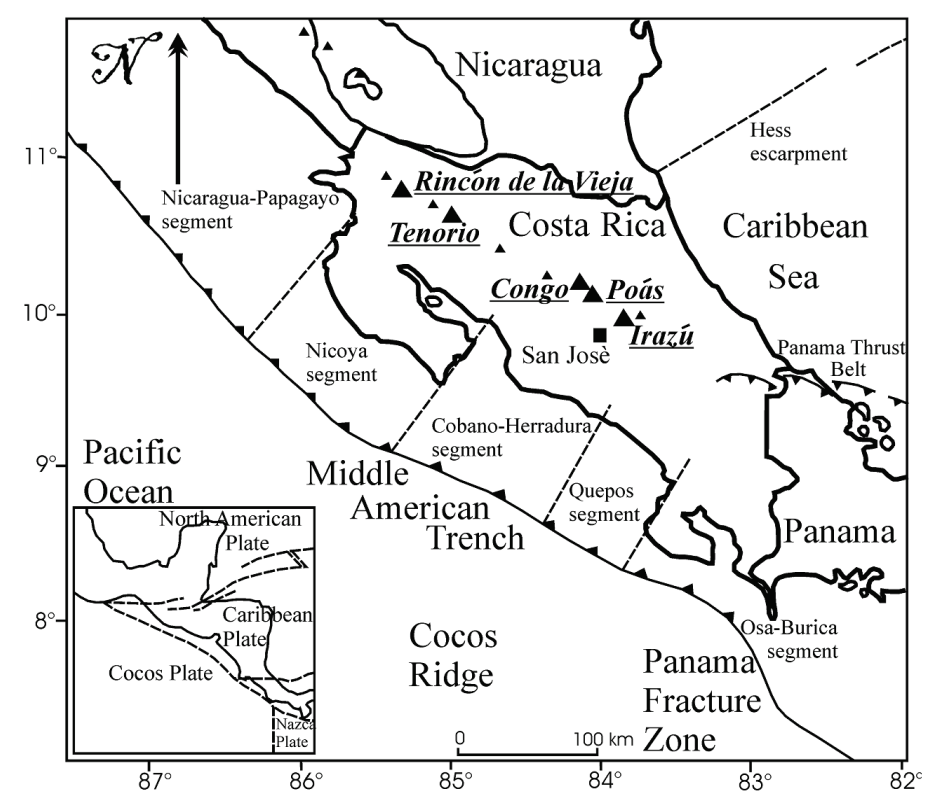

Fig. 1. Schematic map of Costa Rica and location of the main crater lakes.

This paper presents the main morphometric parameters and vertical distribution of the chemical and isotopic composition of water and dissolved gases at the Hule and Congo (Bosque Alegre caldera, Congo volcano), Irazú (Irazú volcano), Botos and Caliente (Poás volcano), Tenorio (Tenorio volcano) and Rincón Crater (Rincón de la Vieja volcano) lakes. The aim is to constrain the main processes controlling the physicalchemical features of these basins and their possible relations with the activity level of the hosting volcanic systems, by using previously published (Vaselli et al. 2003a; Tassi et al. 2005) and original data.

\section{GEOLOGICAL SETTING AND VOLCANIC HISTORY}

Costa Rica is characterized by a complex tectonic setting related to the subduction of the Cocos Plate beneath the Caribbean Plate (Fig. 1) at a rate of about 10 $\mathrm{cm} \mathrm{y}^{-1}$ (Johnston \& Thorkelstone 1997). This collisional process has caused, since the Middle Tertiary, an intense volcanic activity resulting in the formation of a Quaternary volcanic range. This includes i) the Cordillera de Guanacaste to the NW and ii) the Cordillera Central to the SE, both lying on a regional ignimbritic plateau (Montero et al. 1995). The former consists of five stratovolcanoes (Cacao-Orosi, Rincón de la Vieja, Miravalles, Tenorio and Arenal) mainly composed of basaltic andesite to andesitic products. The Cordillera Central has five stratovolcanoes (Platanar-Porvenir, Poás, Barba, Irazú, and Turrialba) with lava flows and pyroclastic deposits, whose composition varies from basaltic to dacitic and andesitic (Castillo 1984). The volcanic activity in Costa Rica in the last 25,000 years has mainly been characterized by phreatic and phreatomagmatic eruptions, with rare plinian eruptions (Alvarado et al. 1992).

\subsection{Poás volcano}

Poás (2708 $\mathrm{m}$ a.s.l.) is part of the Cordillera Central, $35 \mathrm{~km} \mathrm{NE}$ of San José (Fig. 1), and is one of the most active volcanoes of Costa Rica. The summit area comprises three N-S oriented cones: 1) Von Franzius to the $N$, 2) Active Crater, which contains an extremely acidic lake (Caliente lake), and 3) Botos to the SE, where a second lake (Botos) is hosted. Poás volcanic edifice is mainly consisting of calc-alkaline basaltic and andesitic volcanic products (Prosser \& Carr 1987). The last lava flow (7540 years B.P.) was produced by the Botos cone (Prosser 1985). Poás historical activity (since 1828) has been characterized by geyser-like and rare phreatomagmatic eruptions from the Active Crater (Krushensky \& Escalante 1967; Casertano et al. 1983). The material ejected during the 1953-54 explosive events formed a 40-m-high cone that presently occupies most of the NW sector of the Active Crater. In April and May 1989 and during 1990, the Caliente lake completely dried out and deposits of liquid sulphur were observed (Oppenheimer 1992). In the following ten years, the restored lake water has shown strong compositional variations (Martinez et al. 2000). The hydrothermal activity at the Active Crater has progressively increased since 2001 (Vaselli et al. 2003a), and from 2006 to 2008 several phreatic eruptions took place (Fernandez et al. 2007; Duarte \& Fernandez 2007). Presently, strong fumaroles discharge hot (up to $322{ }^{\circ} \mathrm{C}$ in November 2008) magmatic-related fluids from the lake bottom and the E-NE inner flank.

\subsection{Irazú volcano}

Irazú volcano, a composite stratovolcano $(3432 \mathrm{~m}$ a.s.1.), lies about $25 \mathrm{~km}$ E of San José (Fig. 1), and has a 
very complex structure, being constituted by several summit craters and a large number of parasitic cones on its flanks. Its edifice, having a predominant calc-alkaline basaltic-andesite and andesitic composition, developed in the early Holocene (Krushensky 1972; Clark 1993). The volcano summit consists of an E-W oriented ridge, likely produced by gravitational collapses (Pavanelli et al. 2004), formed by several independent vents. The historical eruptions are mainly characterized by strombolian and vulcanian activity from the westernmost crater (Main Crater). The last event, in 1963-65 (Murata et al. 1966), produced more than 40 lahars, some of which reached the city of Cartago. In 1994, part of the northern flank collapsed generating a large debris-flow that flowed $\mathrm{N}$ for several tens of km (Barboza et al. 1994) likely triggered by a phreatic explosion (e.g., Alvarado et al. 2006, Clark et al. 2006). Presently, fumarole emissions from the northern outer flank reach $80{ }^{\circ} \mathrm{C}$ (March 2008), likely related to a well-developed hydrothermal system, whereas Main Crater, which has a diameter of $690 \mathrm{~m}$ and a depth of $150 \mathrm{~m}$, hosts a permanent lake where bubbling gas emissions occur mainly in the NE part of the crater.

\subsection{Bosque Alegre caldera (Congo volcano)}

The Congo volcanic complex, located $10 \mathrm{~km} \mathrm{~N}$ of Poás volcano, formed about 3000 years ago (Melson et al. 1988). It likely represents the remnant of a former twin volcano, whose southern cone (Cerro Congo) is the only one still preserved (Bergoeing \& Brenes 1978). Little information is available about the geological and structural features of the Bosque Alegre caldera, located in the NE flank of the Congo volcano (Dondoli et al. 1968; Saenz 1971). Three lakes are situated within the Bosque Alegre caldera (740 m a.s.1.): Hule, the largest one, Congo and Bosque Alegre. Advances in accelerator mass spectrometry (AMS) radiocarbon dating of fragments of leaves from terrestrial plants and wood recovered in sediments from the Hule lake indicate that the Hule maar formed between 2950 and 2471 calibrated (cal.) years B.P. and that at least two intra-maar eruptions occurred, about 1740 and 670 cal. years B.P. (Horn 2001). Two events of lake overturn likely occurred prior to 1989 and in 1997, respectively (OVSICORI-UNA 1996; Gocke 1996-1997; Haberyan $\&$ Horn 1999). As also reported by nearby settlers, these phenomena were marked by sudden colour changes and death of fishes and birds.

\subsection{Tenorio volcano}

Tenorio (1916 m a.s.l.) is a complex basaltic-andesite stratovolcano pertaining to the Cordillera de Guanacaste. The edifice consists of two twin craters aligned along the NNW-ESE regional trend. The Tenorio volcanic complex lies on a Pre-Pleistocene basaltic-andesite basement covered by eruptive sequences consisting of alternate lava and pyroclastic deposits (Herrera
Cabezas 1990). No historic volcanic activity has been reported from this volcano, although a legend known by the local population tells about an eruption (never documented) in 1816 (Alvarado 1993). Fumarolic activity and thermal discharges are relatively widespread in the outer NE flank of the volcano (Vaselli et al. 2003b). Exploratory geothermal wells have produced no significant results (Moya et al. 2006; Moya \& DiPippo 2007). Tenorio lake is located in a remote area close to the volcano summit.

\subsection{Rincón de la Vieja volcano}

Rincón de la Vieja (1916 m a.s.1.), located at about $25 \mathrm{~km} \mathrm{NE}$ of the town of Liberia (Fig. 1), is a basalticandesite stratovolcano (Kempter et al. 1996) whose summit consists of seven NW-oriented nested craters. Early volcanism was dominated by lava flows, whereas plinian activity had increased with time (Barquero \& Segura 1983). The last eruption with a significant juvenile magmatic component took place 3500 years B.P. (Alvarado et al. 1992). Frequent phreato-magmatic and phreatic eruptions have occurred since 1851 (Boudon et al. 1996). Several thermal springs presently discharge from the outer flanks of the volcanic edifice (Kempter \& Rowe 2000; Tassi et al. 2005). The active crater, which hosts the highly acidic Rincón Crater lake, is characterized by intense fumarolic emission (Tassi et al. 2005) seeping out from the lake and the inner crater walls. A cold crater lake is located within the Santa Maria volcano, and a permanent freshwater lake ("Laguna") is near the active crater (Baker 1987).

\section{MATERIAL AND METHODS.}

\subsection{Bathymetry and sampling techniques}

The collection of water and dissolved gas samples along the vertical profiles of the Hule, Irazú, Botos (February 2001) and Caliente (February 2001 and 2007) lakes was carried out with a tube (6 $\mathrm{mm}$ in diameter) of Rilsan, a plastic material impermeable to both water and gas. Once one end of the Rilsan tube was lowered to the chosen depth, water was pumped up to the surface by means of a $150 \mathrm{~mL}$ glass syringe, connected to the other end of the tube via a three way valve, and transferred into the storage containers (Tassi et al. 2004b; 2009). All water samples were collected after the displacement of a water volume double than that of the inner volume of the tube (about $0.03 \mathrm{dm}^{3} \mathrm{~m}^{-1}$ ). The free gas phase released from water during the suction operated by the syringe was stored into $100 \mathrm{~mL}$ glass flasks tapped with teflon valves. To perform water and gas sampling along the vertical profiles, the point above the deepest spot of each lake was reached by using a $2.30 \mathrm{~m}$ long inflatable raft. A wooden raft was assembled and used under a rubber raft covered with two folded plastic tarps to minimize the contact with the highly acidic water of the Caliente lake. The sampling profiles are described in table 1. 


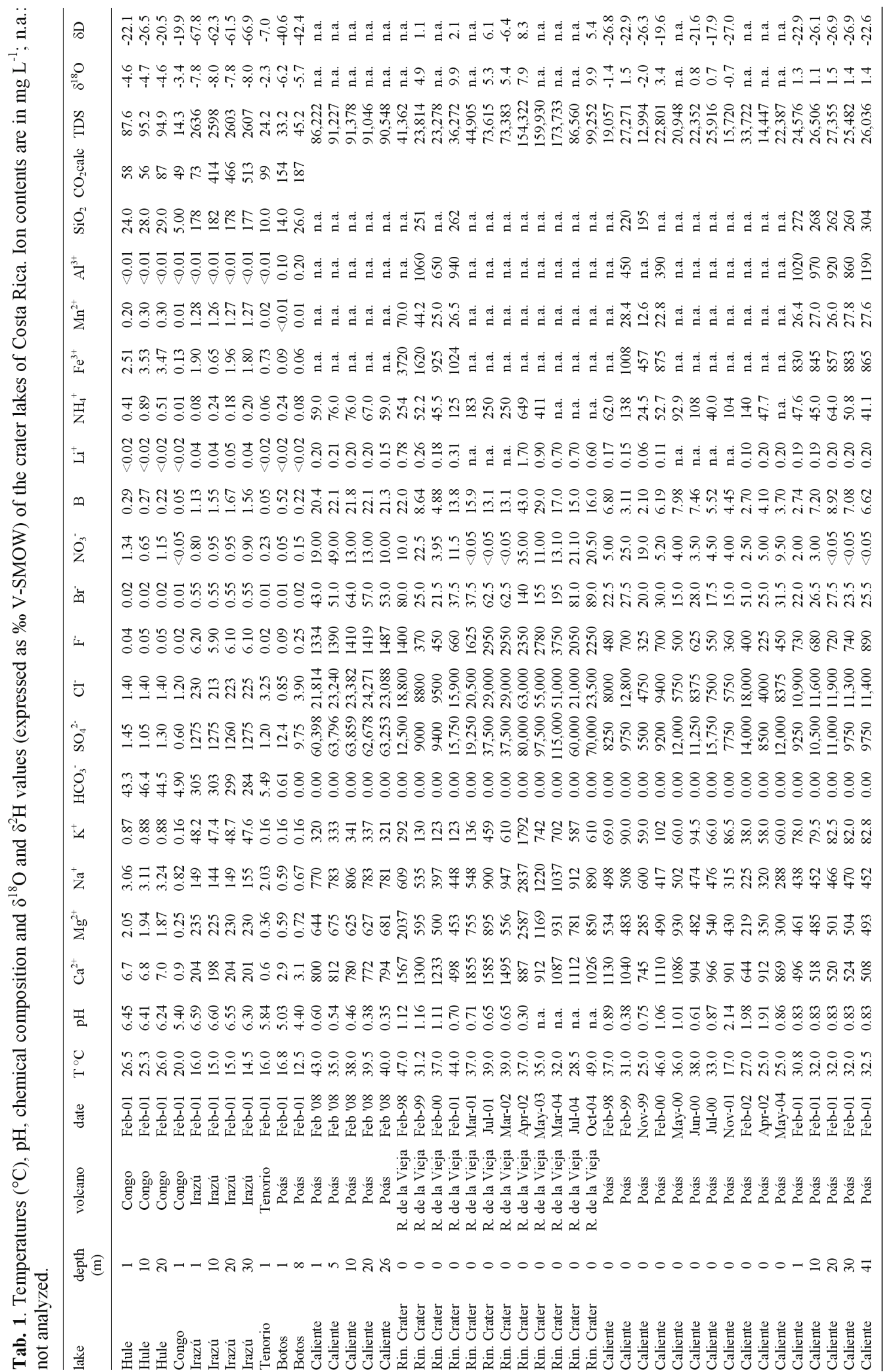



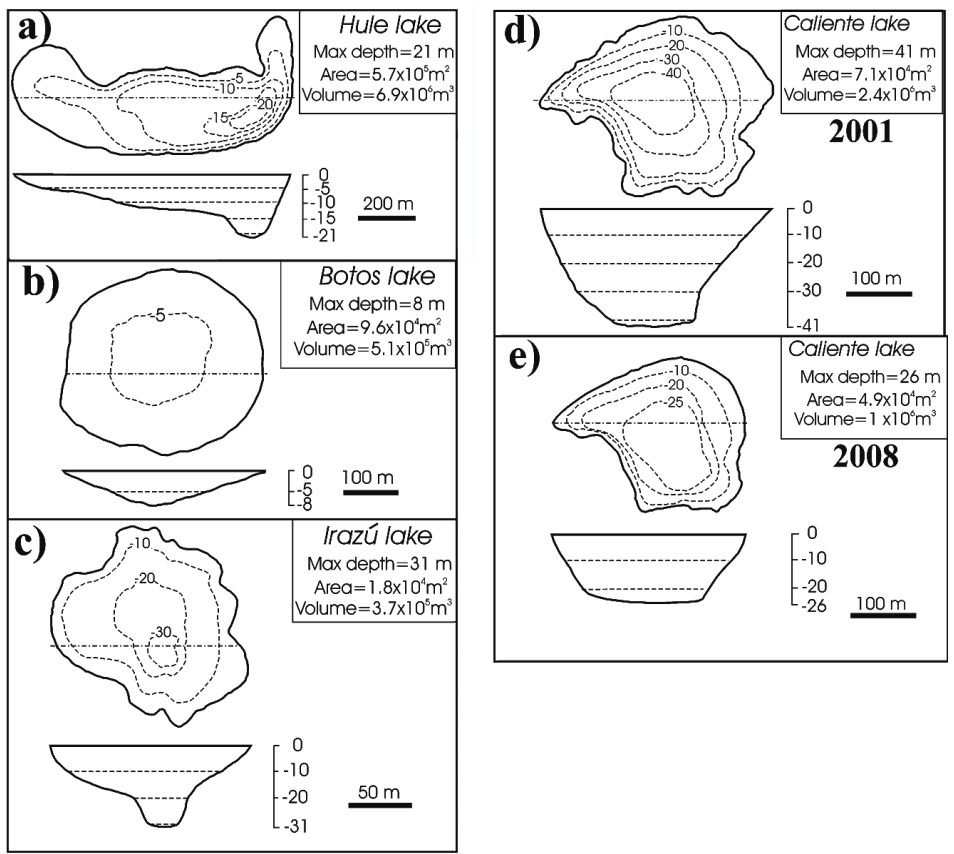

Fig. 2. Reconstruction of the shape and the morphology of the (a) Hule, (b) Botos, (c) Irazú and (d-e) Caliente lakes.

At the Tenorio and Congo lakes, where the maximum depths are 2 and $14.9 \mathrm{~m}$, respectively (Horn \& Haberyan 1993), water samples were taken only from the lake surface. Aside from direct sampling performed in February 2001 (Tassi et al. 2003a), the high flux of acidic gases released from the Rincón Crater lake has prevented close access and vertical sampling in the lake. Thus, lake waters were collected from the crater rim with a fishing pole bearing a plastic bottle.

The bathymetric profiles of the Hule, Caliente, Botos and Irazú lakes were carried out with a Humminbird Legend 1005 portable Eco-sonar. The morphologic images were produced with the Surfer 6.0 software package.

\subsection{Analytical methods}

Temperature and $\mathrm{pH}$ values and $\mathrm{HCO}_{3}^{-}$concentrations (acidimetric titration) were measured in the field. Water samples were analyzed for anions $\left(\mathrm{Cl}^{-}, \mathrm{SO}_{4}{ }^{2-}\right.$, $\mathrm{NO}_{3}^{-}, \mathrm{Br}^{-}$and $\mathrm{F}^{-}$) by ion-chromatography (Dionex DX100), whereas cations $\left(\mathrm{Na}^{+}, \mathrm{K}^{+}, \mathrm{Ca}^{2+}, \mathrm{Mg}^{2+}, \mathrm{Fe}^{3+}, \mathrm{Mn}^{2+}\right.$ and $\mathrm{Li}^{+}$) were determined by AAS (Perkin-Elmer AAnalyst 100). $\mathrm{SiO}_{2}, \mathrm{Al}^{3+}, \mathrm{NH}_{4}^{+}$and Boron were analyzed by molecular spectrophotometry. The analytical errors for IC, AAS and colorimetry were 5, 3 and $\leq 10 \%$, respectively.

The ${ }^{18} \mathrm{O} /{ }^{16} \mathrm{O}$ and $2 \mathrm{H} / 1 \mathrm{H}$ isotopic ratios (expressed as $\delta^{18} \mathrm{O}$ and $\delta \mathrm{D} \% \mathrm{~V}$-SMOW, respectively) were determined with a Finningan Delta Plus XL mass spectrometer. Water samples were equilibrated with $\mathrm{CO}_{2}$ for the analysis of the $\delta^{18} \mathrm{O}$ values (Epstein \& Mayeda 1953). The $\delta \mathrm{D}$ values were measured on $\mathrm{H}_{2}$ obtained after the reaction of $10 \mu \mathrm{L}$ of water with metallic zinc at $500{ }^{\circ} \mathrm{C}$, following the analytical method proposed by
Coleman et al. (1982). EEZ-3 and EEZ-4, calibrated vs $\mathrm{V}-\mathrm{SMOW}$ and SLAP reference standards, were used as external standards. The experimental error was \pm 0.1 and $\pm 1 \%$ for the $\delta^{18} \mathrm{O}$ and $\delta \mathrm{D}$ values, respectively.

The composition of the inorganic compounds in the dissolved gas phase $\left(\mathrm{CO}_{2}, \mathrm{~N}_{2}, \mathrm{O}_{2}, \mathrm{Ar}, \mathrm{Ne}, \mathrm{H}_{2}\right.$ and $\left.\mathrm{He}\right)$ was determined with a gas-chromatograph (Shimadzu 15a) equipped with a Thermal Conductivity Detector (TCD). Methane and $\mathrm{CO}$ (after conversion to $\mathrm{CH}_{4}$ at $400{ }^{\circ} \mathrm{C}$ using a Shimadzu MTN-1 methanizer), were analyzed with a Shimadzu 14a gas-chromatograph equipped with a Flame Ionization Detector (FID) (Tassi et al. 2004a). Dissolved $\mathrm{CO}_{2}$ concentrations (Tab. 1) were calculated from the total carbonate concentrations, measured by automatic titration (Titroprocessor Metrohm 636) with $0.5 \mathrm{M} \mathrm{HCl}$, in water samples collected in $100 \mathrm{~mL}$ glass bottles containing $10 \mathrm{~mL}$ of a $1 \mathrm{M} \mathrm{Na}_{2} \mathrm{CO}_{3}$ solution, according to the following reaction:

$$
\mathrm{H}_{2} \mathrm{O}+\mathrm{CO}_{2}+\mathrm{CO}_{3}{ }^{2-} \leftrightarrow 2 \mathrm{HCO}_{3}^{-}
$$

The ${ }^{13} \mathrm{C} /{ }^{12} \mathrm{C}$ ratio (expressed as $\delta^{13} \mathrm{C} \%$ V-PDB) of $\mathrm{CO}_{2}$ collected from the Caliente lake was determined with a Finningan Delta S mass spectrometer after standard extraction and purification procedures of the gas mixtures (Evans et al. 1998; Vaselli et al. 2006). Internal (Carrara and San Vincenzo marbles) and international (NBS18 and NBS19) standards were used for estimation of external precision. Analytical error is $\pm 0.05 \%$.

\section{RESULTS}

\subsection{Bathymetry and shape of crater lakes}

Bathymetric maps for the Hule, Botos, Caliente and Irazú lakes are shown in figure 2a-d. 
Hule lake is characterized by an uncommon halfmoon shape (Fig. 2a), because of the presence of a secondary cone near the northern shore, and which separates Hule and Congo lakes. Hule lake has a maximum depth of $21 \mathrm{~m}$ close to the SW shore, and a volume of $6.9 \times 10^{6} \mathrm{~m}^{3}$. Botos and Irazú lakes have a regular circular shape (Fig. 2b,c) with mean diameters of about 350 and $150 \mathrm{~m}$, maximum depths of 8 and $31 \mathrm{~m}$ and volumes of $5.1 \times 10^{5}$ and $3.7 \times 10^{5} \mathrm{~m}^{3}$, respectively. In February 2001 the Caliente lake had a mean diameter of $300 \mathrm{~m}$, a maximum depth of $41 \mathrm{~m}$ and a volume of $2.4 \times 10^{6} \mathrm{~m}^{3}$ (Fig. 2d). However, the water level has strongly changed in time. In March 2008, the lake diameter, maximum depth and volume were $250 \mathrm{~m}, 26$ $\mathrm{m}$ and $1 \times 10^{6} \mathrm{~m}^{3}$, respectively (Fig. 2e). The main morphological features of the Costa Rica crater lakes can be summarized by a dimensionless parameter, known as "depth-ratio" (Carpenter 1983), which is the ratio between the average depth and the maximum depth, the former being equal to the ratio between the volume and the surface area of the lake. This parameter may predict if a lake can be affected by stratification, e.g. the higher the depth-ratios, the higher the probability of stratification (Hutchinson 1957). The depth-ratios of Botos, Hule, and Irazú lakes are 0.66, 0.57 and 0.65. According to the heuristic classification of the shapes of lake basins proposed by Carpenter (1983), these values are consistent with the so-called ellipsoid shape (whose typical values are comprised between 0.5 and 0.66 ), which can be considered a common feature for lake basins in volcanic environments. Conversely, Caliente lake in 2001 and 2007 shows depth-ratio values of 0.82 and 0.78 , respectively, approximating a steep-sided frustum model (corresponding to steep sides and flat bottom; Lehman 1975), typical of lakes of recent formation and affected by elevated sedimentation rates.

\subsection{Water chemical and isotopic composition}

Temperature and $\mathrm{pH}$ values, $\delta^{18} \mathrm{O}$ and $\delta \mathrm{D}$ ratios and chemical composition of the crater lakes are listed in table 1. Rincón Crater lake was characterized by a relatively high temperature (up to $49{ }^{\circ} \mathrm{C}$ ), caused by the conspicuous inputs from the lake bottom of hot fluids related to the strong activity characterizing the Rincón de la Vieja magmatic-hydrothermal system. Phreatic eruptions have indeed frequently occurred between February 1998 and October 2004, causing strong changes of water level and chemistry (Tassi et al. 2005 and references therein). Relatively high temperatures (up to 46 ${ }^{\circ} \mathrm{C}$ ) were also measured at the Caliente lake, likely because of the presence of numerous sub-lacustrine fumaroles fed by a hydrothermal system, permanently affected by inputs of high-temperature volatiles (Vaselli et al. 2003a) released from a shallow $(\approx 500 \mathrm{~m}) \mathrm{mag}$ matic body (Rowe et al. 1995). The unusual low temperature $\left(17^{\circ} \mathrm{C}\right)$ measured in November 2001 was likely due to the influence of heavy rains just before water sampling. Temperatures measured at Caliente along the vertical profile in 2008 (up to $43{ }^{\circ} \mathrm{C}$ ) indicated the virtual absence of any significant thermal stratification. In 2001 the lake temperatures was relatively low $(<32.5$ $\left.{ }^{\circ} \mathrm{C}\right)$ (Vaselli et al. 2003a), likely in relation to heavy rains affecting the area, as also testified by the relatively large volume of the lake in that period (Fig. 2e, f). No significant temperature variations were recorded in the water columns of the Hule (between 25.3 and $26.5^{\circ} \mathrm{C}$ ) and Irazú lakes (between 14.5 and $16{ }^{\circ} \mathrm{C}$ ), whereas the temperature measured at the surface of the Botos lake $\left(16.8^{\circ} \mathrm{C}\right)$ was significantly higher than that measured at the lake bottom $\left(12.5^{\circ} \mathrm{C}\right)$, and was likely because of sun exposure.

Hule, Botos, Congo and Tenorio lakes had an acidic $\mathrm{pH}$ (ranging from 4.44 to 6.45 ) and relatively low TDS (Total Dissolved Solids) values $\left(<100 \mathrm{mg} \mathrm{L}^{-1}\right)$. Irazú lake had higher TDS $\left(\approx 2,600 \mathrm{mg} \mathrm{L}^{-1}\right)$ and $\mathrm{pH}$ (up to 6.6) values, whereas the Caliente and Rincón Crater lakes were characterized by extremely high TDS values (up to 91,449 and $173,733 \mathrm{mg} \mathrm{L}^{-1}$, respectively) and extremely low $\mathrm{pH}$ (between 0.30 and 2.14). The amount of dissolved solids is on average significantly higher with respect to other highly acidic crater lakes worldwide, e.g. Ruapehu, New Zealand (Christenson 2000), Kawah Ijen, Indonesia (Delmelle et al. 2000), Santa Ana, El Salvador (Bernard et al. 2004); Copahue, Argentina (Varekamp et al. 2009). The Hule and Congo lakes have displayed a $\mathrm{Ca}(\mathrm{Mg})-\mathrm{HCO}_{3}^{-}$composition, typical of worldwide superficial waters and shallow aquifers, whereas the Tenorio lake had a Na-Cl composition (Fig. 3).

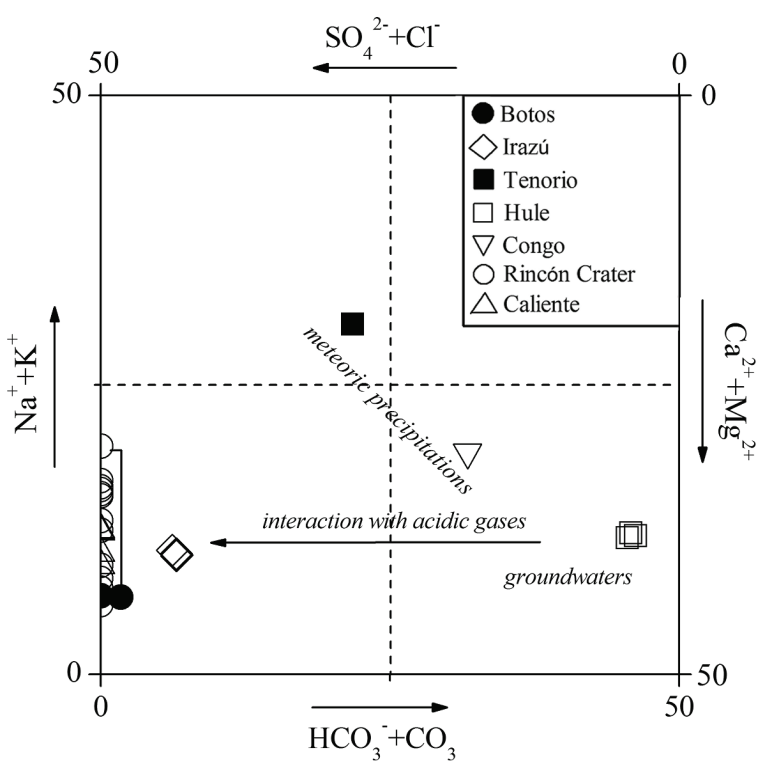

Fig. 3. Langelier-Ludwig (1942) diagram for the water samples from the Hule (open square), Irazú (open diamond), Caliente (open up-triangle), Botos (closed circle), Rincón Crater (open circle), Congo (open down-triangle) and Tenorio (closed square) lakes. 
Tab. 2. Chemical composition and $\delta^{13} \mathrm{C}$ in $\mathrm{CO}_{2}$ (expressed as $\% \mathrm{~V}-\mathrm{PDB}$ ) values of the dissolved gases from crater lakes of Costa Rica. Gas contents are in \% by vol.; n.a.: not analyzed.

\begin{tabular}{lccccccccccc}
\hline lake & depth $(\mathrm{m})$ & $\mathrm{CO}_{2}$ & $\mathrm{~N}_{2}$ & $\mathrm{Ar}$ & $\mathrm{O}_{2}$ & $\mathrm{CH}_{4}$ & $\mathrm{Ne}$ & $\mathrm{H}_{2}$ & $\mathrm{He}$ & $\mathrm{CO}$ & $\delta^{13} \mathrm{C}$ \\
\hline Hule & 20 & 1.713 & 92.76 & 2.215 & 3.315 & $<0.0001$ & 0.0010 & $<0.0001$ & $<0.0001$ & $<0.0001$ & n.a. \\
Irazú & 30 & 39.47 & 50.33 & 0.698 & 9.441 & 0.0578 & 0.0005 & 0.0011 & 0.0024 & $<0.0001$ & n.a. \\
Botos & 8 & 0.042 & 73.06 & 1.872 & 25.02 & 0.0024 & 0.0009 & $<0.0001$ & $<0.0001$ & $<0.0001$ & n.a. \\
Caliente & 1 & 3.796 & 76.69 & 1.954 & 17.45 & $<0.0001$ & 0.0009 & 0.115 & $<0.0001$ & $<0.0001$ & n.a. \\
Caliente & 5 & 6.631 & 76.13 & 1.712 & 15.01 & $<0.0001$ & 0.0008 & 0.511 & $<0.0001$ & 0.0015 & -2.9 \\
Caliente & 10 & 12.11 & 70.54 & 1.215 & 15.48 & 0.0001 & 0.0008 & 0.654 & $<0.0001$ & 0.0025 & -3.0 \\
Caliente & 20 & 16.52 & 68.25 & 0.874 & 13.21 & 0.0001 & 0.0006 & 1.145 & $<0.0001$ & 0.0045 & -3.0 \\
Caliente & 26 & 24.95 & 61.24 & 0.689 & 11.88 & 0.0002 & 0.0005 & 1.215 & $<0.0001$ & 0.0245 & -21.0 \\
Caliente & 1 & 2.695 & 76.72 & 0.994 & 18.67 & 0.0002 & 0.0006 & 0.919 & $<0.0001$ & 0.0035 & -3.0 \\
Caliente & 20 & 13.44 & 67.91 & 0.954 & 16.51 & 0.0001 & 0.0006 & 1.181 & $<0.0001$ & 0.0075 & -3.3 \\
Caliente & 41 & 17.91 & 64.54 & 0.745 & 15.78 & 0.0003 & 0.0005 & 1.007 & $<0.0001$ & 0.0150 & -33.6 \\
\hline
\end{tabular}

By considering the extremely low TDS value (24.2 $\mathrm{mg} \mathrm{L}^{-1}$ ), this chemical signature may be ascribed to meteoric precipitation. Botos and Irazú lakes had a similar composition $\left(\mathrm{Mg}-\mathrm{SO}_{4}\right.$ and $\mathrm{Ca}-\mathrm{SO}_{4}$, respectively), although their TDS values showed a difference of two orders of magnitude (Tab. 1). Caliente and Rincón Crater lakes showed a $\mathrm{Ca}(\mathrm{Mg})-\mathrm{Cl}\left(\mathrm{SO}_{4}\right)$ composition (Fig. 3) that can be regarded as a common feature for crater lakes in active volcanic systems (Casadevall et al. 1984; Christenson \& Wood 1993; Delmelle \& Bernard 1994). Fluoride concentrations were very high at both the Caliente and Rincón Crater lakes (up to 1419 and $3750 \mathrm{mg} \mathrm{L}^{-1}$, respectively), where those of B and $\mathrm{NH}_{4}{ }^{+}$, which are commonly associated to hot-fluid inputs, are enriched in both these lakes (up to 22 and $649 \mathrm{mg} \mathrm{L}^{-1}$, respectively). In contrast, the Irazú, Tenorio, Botos, Congo and Hule lakes had relatively low concentrations of $\mathrm{F}^{-}, \mathrm{B}$ and $\mathrm{NH}_{4}^{+}$(up to 6.2, 1.67 and $0.89 \mathrm{mg} \mathrm{L}^{-1}$, respectively). $\mathrm{Fe}^{3+}, \mathrm{Mn}^{2+}$ and $\mathrm{Al}^{3+}$ concentrations were abundant in the two hyper-acidic lakes (up to 3720,70 and $1190 \mathrm{mg} \mathrm{L}^{-1}$, respectively), whereas they did not exceed $3.5\left(\mathrm{Fe}^{3+}\right), 1.3\left(\mathrm{Mn}^{2+}\right)$ and $0.2\left(\mathrm{Al}^{3+}\right)$ $\mathrm{mg} \mathrm{L}^{-1}$ in those lakes characterized by $\mathrm{pH} \geq 4.4$. Lithium concentrations were relatively low $\left(<1.7 \mathrm{mg} \mathrm{L}^{-1}\right)$ in all the lakes, whereas $\mathrm{NO}_{3}{ }^{-}$concentrations, present at minor amounts in the Irazú, Tenorio, Botos, Congo and Hule lakes, had extremely strong variations (ranging from $<0.05$ to $49 \mathrm{mg} \mathrm{L}^{-1}$ ) in time at Caliente and Rincón Crater lakes. The concentrations of $\mathrm{Br}^{-}$were essentially correlated to those of $\mathrm{Cl}^{-}$. Silica concentrations varied from 5 (Congo) to $304 \mathrm{mg} \mathrm{L}^{-1}$ (Caliente lake in 2001 at the depth of $41 \mathrm{~m}$ ).

The values of $\delta^{18} \mathrm{O}$ and $\delta \mathrm{D}$ values covered a wide range, varying from -8 to 9.9 and -67.8 and $8.3 \% \mathrm{~V}$ SMOW, respectively. The lowest values are those of Irazú, whereas the most positive were related to Rincón Crater. The distribution of the $\delta^{18} \mathrm{O}$ and $\delta \mathrm{D}$ values along the vertical profiles of the Hule, Irazú, Botos and Caliente (2001 data) lakes (Tab. 1) indicated that isotopic stratification can be considered negligible.

\subsection{Dissolved gas composition}

Chemical composition and $\delta^{13} \mathrm{C}-\mathrm{CO}_{2}$ values of the dissolved gas samples are shown in table 2. The com- position of the gas fraction collected by our sampling method depends on the force applied to the syringe, since the composition of the gas phase released from the water differed from that of the whole dissolved gas mixture. Each gas species has indeed a distinct behaviour in response to the stripping process, being characterized by a different solubility. However, these data are useful to detect anomalous concentrations of non-atmospheric originated gas compounds, such as $\mathrm{CO}_{2}$ and $\mathrm{CH}_{4}$, as also supported by the results of analogous investigations (e.g., Kusakabe 1996).

Nitrogen was the most abundant gas component in all the analyzed samples, followed by $\mathrm{O}_{2}$ concentrations that at the Irazú and Caliente lakes were relatively high ( 9.4 and $15.8 \%$ by vol., respectively) even in the deeper water strata. This suggests an efficient water vertical circulation able to promote frequent mixing of shallow and deep waters preventing the formation of anoxic hypolimnion. In contrast, at the bottom of Hule lake the $\mathrm{O}_{2}$ concentration $(3.3 \%$ by vol.) was almost one order of magnitude lower than expected on the basis of the $\mathrm{O}_{2} / \mathrm{Ar}$ ratios for ASW (20.24 for pure water at $30{ }^{\circ} \mathrm{C}$, respectively). Relatively high dissolved $\mathrm{CO}_{2}$ concentrations were measured in samples collected from the maximum depths of the Irazú (39.47\% by vol.) and Caliente lakes (17.91 and $24.95 \%$ by vol. in 2001 and 2007, respectively). Caliente lake water samples have also shown significant concentrations of $\mathrm{H}_{2}$ and $\mathrm{CO}$ (up to 1.18 and $0.015 \%$ by vol., respectively). At Botos lake the dissolved gas phase was essentially constituted by atmospheric-related compounds, whereas the Hule lake was marked by a slight enrichment of $\mathrm{CO}_{2}(1.8 \%$ by vol.). Methane was measured in significant concentrations only in the Irazú $(0.058 \%$ by vol.) and Botos lakes $(0.0024 \%$ by vol. $)$.

The distribution of the $\delta^{13} \mathrm{C}-\mathrm{CO}_{2}$ values measured in both 2001 and 2008 along the vertical profile of the Caliente lake showed a sharp variation. The samples collected at the lake bottom had indeed an extremely negative carbon signature (down to -33.6 and $-21 \%$ VPDB, in 2001 and 2008, respectively), whereas the shallower water strata have shown a significant ${ }^{13} \mathrm{C}_{-} \mathrm{CO}_{2}$ enrichment leading to $\delta^{13} \mathrm{C}-\mathrm{CO}_{2}$ values (between -2.9 and $-3.3 \%$ V-PDB) similar to those measured in the 


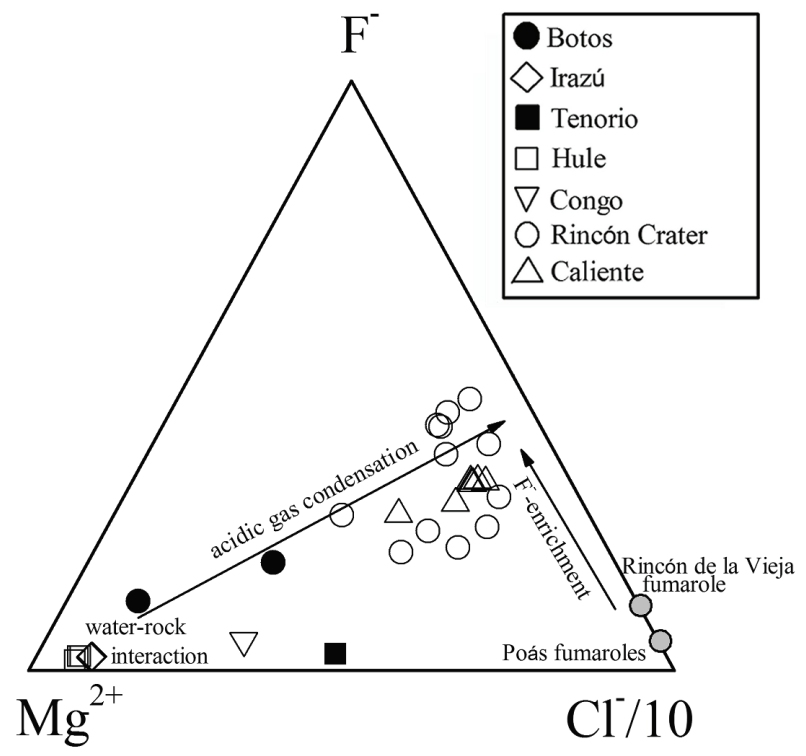

Fig. 4. $\mathrm{F}^{-}-\mathrm{Cl}^{-} / 10-\mathrm{Mg}^{2+}$ ternary diagram for the water samples from the Hule, Irazú, Caliente, Botos, Rincón Crater, Congo and Tenorio lakes. Symbols as in figure 3.

fumaroles located $\mathrm{N}$ and $\mathrm{NE}$ of the lake, i.e -3 and $-6 \%$ (Vaselli et al. 2003a).

\section{DISCUSSION}

\subsection{Processes governing lake-water composition}

According to the classification based on the main physical-chemical parameters proposed by Pasternack \& Varekamp (1997) and Varekamp et al. (2000), the crater lakes of Costa Rica can be grouped, as follows: 1) Rincón Crater and Caliente, which are "high-activity lakes" typical of active volcanic systems (e.g., Ruapheu; Christenson \& Wood 1993); 2) Irazú lake, a "low activity lake" related to hydrothermal venting from lake bottom; 3) Hule, Botos, Congo and Tenorio lakes, where no significant degassing activity is present. The chemical features of the Rincón Crater and Caliente lakes are mainly dependent on fluids from the magmatic systems. Therefore, the complex evolution of the chemicalphysical features of these two lakes in the last 7 years (Tab. 1) was related to i) the input rate of magmatic-related fluids, regulating lake water evaporation, ii) solute contribution from intense rock leaching and iii) rainfall.

As shown in the $\mathrm{F}^{-}-\mathrm{Cl}^{-}-\mathrm{Mg}^{2+}$ ternary diagram (Fig. 4), the Rincón Crater and Caliente lakes were significantly enriched in both $\mathrm{Mg}^{2+}$ and $\mathrm{F}^{-}$with respect to the fumarolic fluids discharged in the same areas (Vaselli et al. 2003a; Tassi et al. 2005). The $\mathrm{Mg}^{2+}$ enrichment was likely due to interaction processes between lake water and host rock. The extremely high $\mathrm{F}^{-}$concentrations may be caused by dissolution of magmatic-related gas compounds. Crater lakes act indeed as condenser for magmatic volatiles, whose solubility in water depends on $\mathrm{pH}$ : at very low $\mathrm{pH}, \mathrm{HCl}$

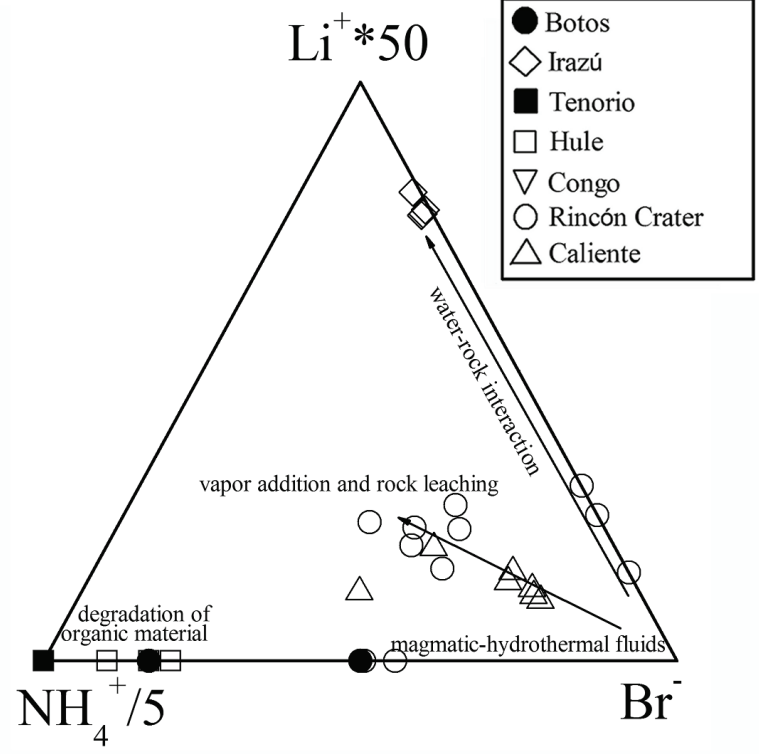

Fig. 5. $\mathrm{Br}^{-}-\mathrm{Li}^{+} * 100-\mathrm{NH}_{4}{ }^{+} / 5$ ternary diagram for the water samples from the Hule, Irazú, Caliente, Botos, Rincón Crater, Congo and Tenorio lakes. Symbols as in figure 3.

solubility abruptly decreases (Symonds et al. 2001) and, consequently, this compound may partly be released to the atmosphere, whereas HF tends to be accumulated in lake water, being completely dissolved. This is also supported by the gas chemistry of Poás (Vaselli et al. 2003a) and Rincón de la Vieja (Tassi et al. 2005) fumaroles (Fig. 4) that are richer in $\mathrm{Cl}$ and poorer in $\mathrm{F}$ with the respect to the lake waters. The Irazú and Hule lakes, whose chemical composition is mainly controlled by water-rock interactions, plot close to the $\mathrm{Mg}^{2+}$ corner (Fig. 4). The relatively high $\mathrm{HCO}_{3}^{-}$and $\mathrm{SO}_{4}{ }^{2-}$ concentrations measured at Irazú (Tab. 1) are related to the $\mathrm{CO}_{2}\left(\mathrm{H}_{2} \mathrm{~S}\right)$-rich thermal fluids that are discharged into the lake from the sub-lacustrine vents. Botos, Congo and Tenorio lakes plot at an intermediate position between the fields of hyperacidic and almost neutral lakes (Fig. 4), because they are largely constituted by meteoric water, as also supported by the extremely low TDS values (Tab. 1).

In the $\mathrm{NH}_{4}^{+}-\mathrm{Li}^{+}-\mathrm{Br}^{-}$ternary diagram (Fig. 5) the different fluid sources feeding the crater lakes can clearly be distinguished. The $\mathrm{NH}_{4}^{+}$enrichment showed by the Tenorio and Congo samples is likely related to degradation of organic material that seems to be the only process active in these lakes, along with the minor contribution of solutes by meteoric waters and water rock interactions. In contrast, Botos lake waters were slightly enriched in $\mathrm{Br}^{-}$, possibly because of the influence of the Poás fumarolic-induced plume. This may explain the low $\mathrm{pH}$ values and the anomalous concentrations of both $\mathrm{Cl}^{-}$and $\mathrm{SO}_{4}{ }^{2-}$ with respect to those of $\mathrm{HCO}_{3}^{-}$(Tab. 1). Irazú was enriched in $\mathrm{Li}^{+}$produced by the dominant water-rock interactions. The distribution of the water samples from the Caliente and Rincón Crater lakes (Fig. 
5) was depending on the balance between addition of i) $\mathrm{HBr}$ and $\mathrm{NH}_{3}$ from the fumarolic sub-lacustrine discharges and ii) $\mathrm{Li}^{+}$from rock leaching.

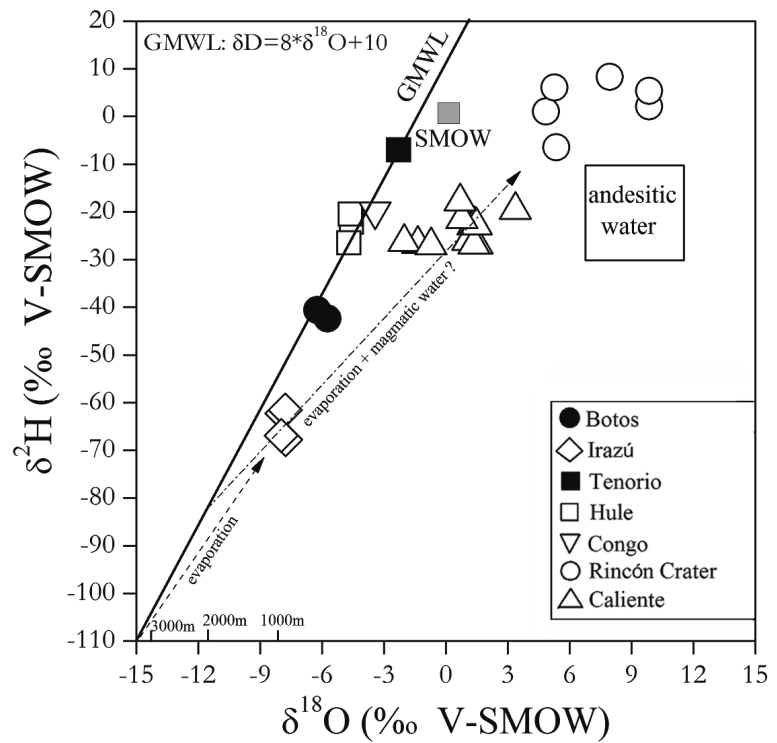

Fig. 6. $\delta^{18} \mathrm{O}-\delta \mathrm{D}$ diagram for the water samples from the Hule, Irazú, Caliente, Botos, Rincón Crater, Congo and Tenorio lakes. The "andesitic water" field is from Taran et al. (1989); the Global Meteoric Water Line (GMWL) from Craig (1961). Symbols as in figure 3 .

In the $\delta^{18} \mathrm{O} v s \delta \mathrm{D}$ diagram (Fig. 6) the Botos, Tenorio, Hule and Congo lakes plot along the Global Meteoric Water Line (GMWL; Craig 1961). In contrast, the Rincón Crater samples, as well as those of Caliente lake, show a strong positive ${ }^{18} \mathrm{O}$-shift that may be attributed to evaporation related to the heating of the lake water, mainly caused by hot fluid inputs. As also suggested by Tassi et al. (2005), such process has presumably masked any isotopic signature deriving from direct contribution of magmatic waters ("Andesitic water"; Taran et al. 1989). The $\delta^{18} \mathrm{O}$ and $\delta \mathrm{D}$ values of the Irazú lake seem to be exclusively related to evaporation of meteoric water, once the effect of the altitude (up to $3300 \mathrm{~m}$ a.s.l.) of the recharge area of this lake is considered (Fig. 6).

\subsection{Chemical and isotopic features of lakes along the vertical profiles}

The chemical and isotopic water compositions of the Irazú, Botos and Hule lakes were basically constant along the vertical profiles (Tab. 1). However, the Irazú and Hule lakes show relative increases with depth of the dissolved $\mathrm{CO}_{2}$ concentrations determined from both the calculated $\mathrm{CO}_{3}{ }^{2-}$ excess [see reaction (1)] (Tab. 1) and the analysis of the gas phase extracted from water (Tab. 2 ). The presence of dissolved- $\mathrm{CO}_{2}$ in the deep strata of the Irazú lake is related to the inputs from the underlying hydrothermal system through the numerous
$\mathrm{CO}_{2}\left(\mathrm{H}_{2} \mathrm{~S}\right)$-rich gas vents that discharge from lake bottom (Tassi et al. 2003b) and that were also responsible for the $\mathrm{SO}_{4}$-dominated composition. At the Hule lake, the relative small increase of $\mathrm{CO}_{2}$ with depth could be ascribed to degradation of organic material, in agreement with the relatively high concentrations of N-compounds along the whole vertical profile, typically produced by bacterial activity (Gocke 1996-1997). However, radiocarbon dating of bulk surface sediments and core samples indicates that isotopically dead carbon entered into the lake (Horn 2001), suggesting that $\mathrm{CO}_{2}$ is released into the lake from a deep source, although at relatively low amounts by considering the low percentage of the measured $\mathrm{CO}_{2}$ (Tab. 2). This hypothesis is consistent with the lack of $\mathrm{CH}_{4}$ (Tab. 2), whose production by bacteria is favoured at reducing conditions, such as those dominating the Hule deep water strata. As already suggested by Haberyan \& Horn (1999), the relatively low concentrations of the main anions (Tab. 1) seem to exclude direct injection of deepwater of volcanic origin. The shallow Botos lake shows no significant thermal and/or compositional stratification. The distribution of the main chemical compounds from the surface to the bottom of the Caliente lake has been already debated by Vaselli et al. (2003a) on the basis of the vertical profile performed in 2001. The main cations have resulted almost constant, whereas $\mathrm{F}^{-}$showed significant increases. In contrast, the $\mathrm{Cl}^{-}$and $\mathrm{SO}_{4}{ }^{2-}$ concentrations followed increasing trends from the lake surface to the depth of $20 \mathrm{~m}$ (up to $10 \%$ of the total abundances) and decreased in the deeper water strata. At the lake bottom both these compounds had concentrations similar to those measured at the surface. The water composition along the vertical profile performed in March 2008 has confirmed the occurrence of this peculiar chemical stratification (Fig. 7a-d). Remarkably, despite the phreatic eruptions occurred from 2006 and the decreasing water level, solute concentrations have not suffered significant variations. These compositional trends may be explained by hypothesizing a complex combination of several processes. Dilution by meteoric precipitations could tentatively be regarded as the main cause for the relatively low $\mathrm{Cl}^{-}, \mathrm{SO}_{4}{ }^{2-}$ and $\mathrm{F}^{-}$concentrations measured at shallow depth. The summit of Poás volcano is indeed characterized by frequent and heavy rainfall. Nevertheless, the almost constant vertical distribution of the concentrations of the main cations, besides that of $\delta^{18} \mathrm{O}$ and $\delta \mathrm{D}$ values (Tab. 1), seems to exclude that rains can really play a dominant role on the behaviour of the main anions in the shallower strata lake. Evaporation of acidic compounds, like $\mathrm{HCl}$ and $\mathrm{H}_{2} \mathrm{~S}$, favoured by the extremely low $\mathrm{pH}$ and the relatively high temperature of the lake, may better fit with the observed phenomena. Dissolution of $\mathrm{HCl}, \mathrm{SO}_{2} \mathrm{H}_{2} \mathrm{~S}$ and $\mathrm{HF}$ from the sub-lacustrine fumaroles in lake water may be invoked to explain the progressive enrichment with depth of $\mathrm{Cl}^{-}, \mathrm{SO}_{4}{ }^{2-}$ and $\mathrm{F}^{-}$. However, only $\mathrm{F}^{-}$con- 


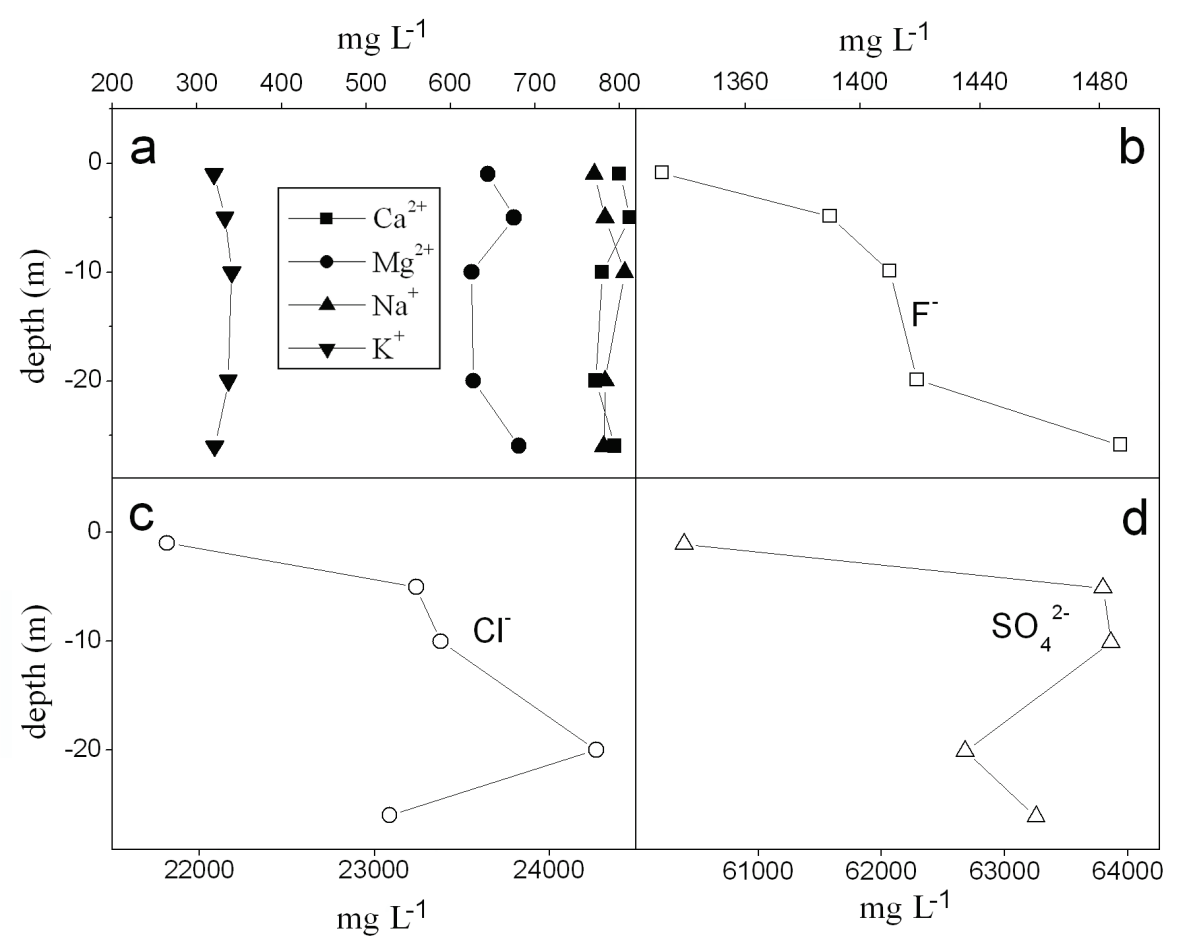

Fig. 7. Vertical profiles of a) $\mathrm{Ca}^{2+}, \mathrm{Mg}^{2+}, \mathrm{Na}^{+}$and $\mathrm{K}^{+}$, b) $\mathrm{F}^{-}$, c) $\mathrm{Cl}^{-}$and d) $\mathrm{SO}_{4}{ }^{2-}$ concentrations for the Caliente lake.

stantly increases with depth. Therefore, at least the behaviour of $\mathrm{SO}_{4}{ }^{2-}$ below the depth of $20 \mathrm{~m}$ is likely to be related to the activity of bacteria that are concentrated close to the water-sediment interface. Culture experiments using different media suggested that the bacteria found in the Caliente lake mainly pertain to Desulfovibrio desulfuricans and Desulfovibrio vulgaris species (Bergamaschi 2002). Such organisms are able to transform $\mathrm{SO}_{4}{ }^{2-}$ to $\mathrm{H}_{2} \mathrm{~S}$ (Postgate \& Campbell 1966). The presence of microbial activity was also supported by the $\delta^{13} \mathrm{C}-\mathrm{CO}_{2}$ values that from surface to the lake bottom passed from the typical values for mantle-related $\mathrm{CO}_{2}$ (Rollison 1993) to values characteristic of an organic source (Tab. 2). Although no isotopic data are available for $\mathrm{CH}_{4}$, the presence of this hydrocarbon in the dissolved gas phase in the deepest portion of Caliente lake (Tab. 2) as originated by biogenic processes cannot be ruled out. Finally, the organic activity is generally considered to be unable to metabolize $\mathrm{Cl}^{-}$, although little is known about the characteristics of the bacteria active in such extreme environmental conditions.

\section{CONCLUSIONS}

The strong fumarolic activity of the Poás and Rincón de La Vieja volcanoes plays an effective control on the chemistry of the two lakes hosted within their main craters. Caliente and Rincón Crater lakes are affected by impressive inputs of hydrothermal/magmatic fluids that have a twofold effect: they add highly soluble compounds and promote intense rock leaching processes. Moreover, the high-flux injection of hot fluids is able to continuously sustain a convective regime that homogenizes the lake temperature and, at least partly, the chemical composition along the vertical profile. However, biochemical processes at the sediment-water interface appear to significantly affect the chemical and isotopic composition of the bottom waters of Caliente lake. The rapid variations in water level at Caliente lake in the last years is to be ascribed to i) strong evaporation, related to periods of high fumarolic emission, and ii) high-rate sediment deposition from the heavily altered lake border, as also suggested by the permanent flat shape of the lake bottom and iii) the recent phreatic activity. The chemical features of the Irazú lake are dominated by water-rock interaction and $\mathrm{CO}_{2}\left(\mathrm{H}_{2} \mathrm{~S}\right)$-rich gas addition from the presently-active hydrothermal system. The lack of significant changes with depth of both the water chemistry and temperature may be related to frequent mixing of the lake water, likely triggered by the cold heavy rains commonly affecting this area. The chemical and physical properties of the lakes characterized by extremely low salinity (Botos, Congo and Tenorio) are mainly regulated by meteoric precipitation, although Botos seems to be significantly affected by contamination from the volcanic plume produced by the Active Crater of Poás. At the Hule lake radiocarbon analyses of lake sediments reveals the presence of volcanic $\mathrm{CO}_{2}$, likely related to the "Poás volcanic alignment" (Malavassi et al. 1990), a zone of apparent crustal weakness that begins from the Poás volcano and extends northward through the Hule maar to the Rio Cuarto maar (Alvarado 1990). Episodes of lake turnover are likely frequent in this lake, especially in January, when 
the air temperature is relatively cold and the weather is rainy and windy (Haberyan \& Horn 1999), as also suggested by the occurrence of fish deaths observed in recent years the local population (Duarte \& Fernandez 1996).

The $\mathrm{CO}_{2}$-rich gas phase detected in the deep waters of Irazú and Caliente lakes is likely from high-flux gas vents discharging from the lake bottoms, although at Caliente the $\delta^{13} \mathrm{C}-\mathrm{CO}_{2}$ values at the maximum depth, as well as the anomalous vertical distribution of the main anions, points to a significant $\mathrm{CO}_{2}$ contribution from microbial colonies. However, the dimensions of these reservoirs are limited by the continuous gas dispersion through lake surface, which is favoured by the dominant convective regime resulting in frequent mixing of water strata. Therefore, in these systems the hazard related to the possible occurrence of Nyos-type gas eruptions can be considered negligible. Although no vertical chemical and isotopic data at Caliente lake were carried prior to the 2006-2008 phreatic eruptions, it seems that significant variations may have occurred. As a consequence, periodic sampling and analysis of the vertical profiles should be conducted at Caliente lake to minimize the volcanic risk for thousands of tourists that visit the National Park of Poás each year. No measurement along the vertical profile of the Rincón Crater lake are available. However, on the basis of the compositional characteristics of the lake surface it is reasonable to argue that the processes regulating the chemistry of this lake at depth should not differ to those acting at Caliente lake.

\section{ACKNOWLEDGEMENTS}

Many thanks are due to the OVSICORI personnel for the logistic support during the various field trips to the Costa Rica crater lakes. Nadia Pavanelli and Angelo Minissale are kindly thanked for their help during some of the field trips in the Costa Rica lakes. F. Capecchiacci and B. Nisi are acknowledged for their help during the chemical analysis of the Rincón Crater and Caliente lakes. Helpful comments of Guido Giordano and an anonymous reviewer are gratefully acknowledged. CNR (Italian Council of Research), ASI (Italian Space Agency) and MIUR (Italian Ministry of Education, University and Research) are thanked for partly supporting the field works of FT, OV, FB and AM.

\section{REFERENCES}

Alvarado, G.E. 1989. Los volcanes de Costa rica. EUNED, San José, Costa Rica: 212 pp.

Alvarado, G.E. 1993. Costa Rica: Land of Vulcanoes. Gallo Pinto press, Cartago, Costa Rica: $174 \mathrm{pp}$.

Alvarado, G.E., M.J. Carr, B.D. Turrin, C.C. Swisher, H.U. Schmincke \& K.W. Hudnut. 2006. Recent volcanic history of Irazú volcano, Costa Rica: Alternation and mixing of two magma batches, and pervasive mixing. In: W.I. Rose, G.J.S. Bluth, M.J. Carr, J., Ewert, L.C. Patino \& J. Vallance (Eds), Volcanic hazards in Central America. Geol. Soc. Am. Special Paper, 412: 259-276.

Alvarado, G.E., S. Kussmaul, S. Chiesa, P.Y. Gillot, H. Appel, G. Worner \& C. Rundle. 1992. Resumen cronoestratigra- fico de las rocas igneas de Costa Rica basado en dataciones radiometricas. J. South. Am. Earth Sci., 6/3: 151-168.

Anzidei, M., M.L. Carapezza, A. Esposito, G. Giordano, L. Tarchini, \& M. Lelli. 2008. The Albano Maar lake high resolution bathymetry and dissolved $\mathrm{CO}_{2}$ budget (Colli Albani District, Italy): Constrains to hazard evoluation. $J$. Volcanol. Geoth. Res., 171: 258-268.

Badruin, M. 1994. Kelut volcano monitoring: Hazards, mitigation and changes in water chemistry prior to the 1990 eruption. Geochem. J., 28: 233-241.

Baker, R.G.E. 1987. Notes on the high altitude freshwater lakes of Volcán Rincón de la Vieja National Park, northern Costa Rica. Brenesia, 27: 47-54.

Barboza, V., E. Fernandez, R. Van der Laat \& E. Malavassi. 1994. Volcan Irazú: actividad eruptive flanco noroeste, 8 de deciembre 1994. Boletin de prensa, 12/94, OVSICORI.

Barquero, J.H. \& J. Segura. 1983. La actividad del volcan Rincón de la Vieja. Bol. Volcanol., 13: 5-10.

Bergamaschi, F. 2002. Studio geochimico di laghi craterici del Costa Rica e manifestazioni ad essi associate. Unpubl. Thesis, Univ. of Florence: $170 \mathrm{pp}$.

Bergoeing, J.P. \& L.G. Brenes. 1978. Laguna Hule, una caldera volcanica. Inst. Geogr. Nac. Costa Rica, Int. Rep., OVSICORI-UNA: 59-63.

Bernard, A., C.D. Escobar, A. Mazot \& R.E. Gutiérrez, 2004. The acid volcanic lake of Santa Ana volcano, El Salvador. In Natural Hazards in El Salvador. Geol. Soc. Am. Special Paper, 375: 121-133.

Blong, R.J. 1984. Volcanic hazard: A sourcebook of the effects of eruptions. Academic Press, Orlando, Florida: 424 pp.

Boudon, G., J.P. Rancon, G. Kieffer, G.J. Soto, H. Traineau \& J.C. Rossignol. 1996. Les eruptions de 1966-1970 et 19911992 du volcan Rincón de la Vieja, Costa Rica: exemple d'activité réecurrente d'un systéme hydromagmatique. C.R. Acad. Sci. Paris, 322: 101-108.

Brantley, S.L., A.M. Agustsdottir \& G.L. Rowe. 1993. Crater lakes reveal volcanic heat and volatile fluxes. Geol. Soc. Am., 3: 175 .

Carpenter, S.R. 1983. Lake geometry: Implications for production and sediment accretion rates. J. Theor. Biol., 105: 273-286.

Casadevall, T.J., S. De La Cruz-Reyna, S. Rose, W.I. Bagley, D.L., Finnegan \& W.H. Zoller. 1984. Crater lake and posteruption hydrothermal activity. El Chichon volcano, Mexico. J. Volcanol. Geotherm. Res., 23: 169-191.

Casertano, L., A. Borgia \& C. Cigolini. 1983. El volcano Poás, Costa Rica: cronologia y caracteristicas de actividad. Geofis. Int., 22: 215-236.

Castillo, R.M. 1984. Geologia de Costa Rica. Editorial de la Universidad de Costa Rica, San José, Costa Rica: 188 pp.

Christenson, B.W. 2000. Geochemistry of fluids associated with the 1995/96 eruption of Mt. Ruapheu, New Zealand: signatures and processes in the magmatic-hydrothermal system. J. Volcanol. Geotherm. Res., 97: 1-30.

Christenson, B.W. \& C.P. Wood. 1993. Evolution of a venthosted hydrothermal system beneath Ruapehu crater. N.Z. Bull. Volcanol., 55: 547-565.

Clark, S.K. 1993. The recent eruptive history of Irazú volcano, Costa Rica: a study of tephra deposits of the last 2,500 years with geochemical and isotopic analysis of the 196365 eruption. Unpubl. Thesis, Univ. of Iowa: $186 \mathrm{pp}$.

Clark, S.K., M.K. Reagan \& D.A. Trimble. 2006. Tephra deposits for the past 2600 years from Irazú volcano, Costa Rica. In: W.I. Rose, G.J.S. Bluth, M.J. Carr, J., Ewert, L.C. Patino \& J. Vallance (Eds), Volcanic hazards in Central America. Geol. Soc. Am. Special Paper, 412: 225234.

Coleman, M.L., T.J. Shepherd, J.E. Rouse \& G.R. Moore. 1982. Reduction of water with zinc for hydrogen isotope analysis. Anal. Chem., 54: 993-995. 
Craig, H. 1961. Isotopic variations in meteoric waters. Science, 133: 1702-1703.

Delmelle, P. \& A. Bernard. 1994. Geochemistry, mineralogy and chemical modelling of the acid Crater lake of Kawah Ijen Volcano, Indonesia. Geochim. Cosmochim. Acta, 58: 2445-2460.

Delmelle, P., A. Bernard, M. Kusakabe, T.P. Fisher \& B. Takano. 2000. Geochemistry of the magmatic-hydrothermal system of Kawah Ijen volcano, East Java, Indonesia. $J$. Volcanol. Geotherm. Res., 97: 31-53.

Dondoli, C., G. Dengo, \& E. Malavassi. 1968. Mapa geologico de Costa Rica. Escala 1:700,000 (compulacion). Direccion Geol. Min. Petrol., San José, Costa Rica.

Duarte, E. \& E. Fernandez. 1996. Muerte de peces en una caldera vulcanica: Laguna de Hule, Bosque Alegre. Int. Rep. OVSICORI-UNA, 10-19 January 1996: 5 pp.

Duarte, E., \& E. Fernandez. 2007. Small phreatic eruption from crater lake on 13 January 2008. Bull. Global Volcan. Network, (BGVN 32:12), 12/2007.

Epstein, S. \& T.K. Mayeda. 1953. Variation of the 18O/16O ratio in natural waters. Geochim. Cosmochim. Acta, 4: 213-224.

Evans, W.C., G.W. Kling, M.L. Tuttle, G. Tanyileke \& L.D. White. 1993. Gas buildup in Lake Nyos, Cameroon: The recharge process and its consequences. Appl. Geochem., 8: 207-221.

Evans, W.C., L.D. White, M.L. Tuttle, G.W. Kling, G. Tanyileke \& R.L. Michel. 1994. Six years of changes at Lake Nyos, Cameroon yield clues to the past and cautions for the future. Geochem. J., 28: 139-162.

Evans, W.C., L.D. White \& J.B. Rapp. 1998. Geochemistry of some gases in hydrothermal fluids from the southern Juan de Fuca ridge. J. Geophys. Res., 15: 305-313.

Fernandez, E., E. Duarte \& W. Saenz. 2007. Products and description from 3 phreatic eruptions occurred on March 2006. Poás Volcano, Costa Rica. Am. Geophys. Union, Fall Meeting 2007, abstract V33A-04.

Giggenbach, W.F. 1974. The chemistry of crater lake, Mt. Ruapheu (New Zealand) during and after the 1971 active period. N.Z. J. Sci., 17: 33-45.

Giggenbach, W.F. 1983. Chemical surveillance of active volcanoes in New Zealand. In: H. Tazieff \& J.C. Sabroux, (Eds), Forecasting Volcanic Events. Elsevier, Amsterdam: 311-322.

Gocke, K. 1996-1997. Basic morphometric and limnological properties of Laguna Hule, a caldera lake in Costa Rica. Rev. Biol. Trop., 44/45: 537-548.

Haberyan, K.A. \& S.P. Horn. 1999. Chemical and physical characteristics of seven volcanic lakes in Costa Rica. Brenesia, 51: 85-95.

Haberyan, K.A., S.P. Horn \& G.V. Umana. 2003. Basic limnology of fifty-one lakes in Costa Rica. Rev. Biol. Trop., 51: 107-122.

Herrera Cabezas D. 1990. UNU Geother. Training Programme, Reykjavik: $35 \mathrm{pp}$.

Horn, S.P. 2001. The age of the Laguna Hule explosion crater, Costa Rica, and the timing of subsequent tephra eruptions: evidence from lake sediments. Rev. Geol. Am. Centr., 24: 57-66.

Horn, S.P. \& K.A. Haberyan. 1993. Physical and chemical properties of Costa Rican lakes. Nat. Geogr. Res. Expl., 9: 86-103.

Hutchinson, G.E. 1957. A treatise on limnology v.1. Geography, Physics and Chemistry. J. Wiley, New York: 1015 pp.

Johnstone, S.T. \& D.J. Thorkelson. 1997. Cocos-Nazca slab windows beneath Central America. Earth Planet. Sci. Lett., 146: 465-474.

Kempter, K.A., S.G. Benner \& S.N. Williams. 1996. Rincón de la Vieja volcano, Guanacaste province, Costa Rica: geology of the south-western flank and hazard implication. $J$. Volcanol. Geotherm. Res., 71: 109-127.
Kempter, K.A. \& G.L. Rowe. 2000. Leakage of Active Crater lake brine through the north flank at Rincón de la Vieja volcano, north-west Costa Rica, and implication for crater collapse. In: Varekamp, J. \& G.L. Rowe (Eds), Crater Lakes. J. Volcanol. Geotherm. Res., 97: 143-159.

Krushensky, R. 1972. Geology of Istaru Quadrangle, Costa Rica. U.S. Geol. Surv. Boll., 1358: 1-46.

Krushensky, R.D. \& G. Escalante. 1967. Activity of Irazù and Poás volcanoes, Costa Rica, November 1964-July 1965. Bull. Volcanol., 31: 75-84.

Kusakabe, M. 1996. Hazardous crater lakes. In: R. Scarpa \& R.I. Tilling (Eds), Monitoring and mitigation of volcano hazards. Springer-Verlag, Berlin: 573-598 pp.

Langelier, W.F. \& H.F. Ludwig. 1942. Graphical method for indicating the mineral character of natural waters. J. Am. Waterworks Assoc., 34: 335-352.

Lehman, J.T. 1975. Reconstructing the rate of accumulation of lake sediment. The effect of sediment focusing. Quatern. Res., 5: 541-550.

Malavassi, E., J.B. Gill \& D. Trimble. 1990. Nuevas dataciones radiométricas del alineamiento volcánico de Poás (Costa Rica): Contribución a la evaluación de peligro volcánicos. Proc. $7^{\text {th }}$ Congreso Geologico de America Central: 37 pp.

Martinez, M., E. Fernandez, J. Valdes, V. Barboza, R. Van del Laat, E. Duarte, E. Malavassi, L. Sandoval, J. Barquero \& T. Marino. 2000. Chemical evolution and volcanic activity of the Active Crater lake of Poás volcano, Costa Rica, 1993-1997. J. Volcanol. Geotherm. Res., 97: 127-141.

Martini, M., L. Giannini, F. Prati, F. Tassi, B. Capaccioni \& P. Iozzelli. 1994. Chemical characters of crater lakes in the Azores and Italy: the anomaly of the Lake Albano. Geochem. J., 28: 173-184.

Melson, W.G., R. Saenz, J. Barquero \& E. Fernandez. 1988. Edad relativa de las erupciones de Cerro Congo y Laguna Hule. Bol. Vulcanol., 19: 8-10.

Montero, W., P.S. Paniagua, S. Kussmaul \& F. River. 1995. Geodynamic map of Costa Rica. Circum-Pacific Council for Energy and Mineral. Res. Earth Sci., 16: 11-17.

Moya, P., E.M. Rodríguez \& A. Mainieri. 2006. Legal barriers to the utilization of geothermal energy in protected areas of Costa Rica. Geotherm. Resour. Council Trans., 30: 1059-1065.

Moya P. \& R. DiPippo. 2007. Unit 5 bottoming binary plant at Miravalles geothermal field, Costa Rica: Planning, design, performance and impact. Geothermics, 36: 63-96.

Murata, K.J., C. Dondoli \& R. Saenz. 1966. The 1963-65 eruption of Irazú volcano, Costa Rica. Bull. Volcanol., 29: 765-796.

Nairn, I.A., C.P. Wood, C.A.Y. Hewson \& P.M. Otway. 1979. Phreatic eruptions of Ruapheu: April 1975. N.Z. J. Geol. Geophys., 22: 155-173.

Oppenheimer, C. 1992. Sulphur eruptions at Volcán Poás, Costa Rica. J. Volcanol. Geotherm. Res., 49: 1-21.

Pasternack, G.B. \& J.C. Varekamp. 1997. Volcanic lake systematics I. Physical constraints. Bull. Volcanol., 58: 528-538.

Pavanelli, N., B. Capaccioni, D. Sarocchi, G. Calderoni, O. Vaselli, F. Tassi, \& E. Duarte. 2004. Geology and stability of the southern flank of Irazú Volcano, Costa Rica. Acta Vulcanol., 1/2: 77-84.

Postgate J.R. \& L.L. Campbell. 1966. Classification of Desulfovibrio species, the non-sporulating sulphate-reducing bacteria. Bacteriol. Rev., 30: 732-738.

Prosser, J.T. 1985. Geology and medium-term temporal magmatic variations found at the summit region of Poás volcano, Costa Rica. Bol. Volcanol., 15: 21-39.

Prosser, J.T. \& M.J. Carr. 1987. Poás volcano, Costa Rica: geology of the summit region and spatial and temporal variations among the most recent lavas. J. Volcanol. Geotherm. Res., 33: 131-146. 
Rice, A. 2000. Rollover in volcanic crater lakes: a possible cause for Lake Nyos type disasters. J. Volcanol. Geotherm. Res., 97: 233-239.

Rollison, H. 1993. Using geochemical data: evaluation, presentation, interpretation. Longman Scientific and Technical, New York: 352 pp.

Rowe, G.L., S. Ohsawa, B. Takano, S.L. Brantley, J.F. Fernandez \& J. Barquero. 1992. Using crater lake chemistry to predict volcanic activity at Poás volcano, Costa Rica. Bull. Volcanol., 54: 494-503.

Rowe, G.L., S.L. Brantley, E. Fernandez \& A. Borgia. 1995. The chemical and hydrologic structure of Poás volcano, Costa Rica. J. Volcanol. Geotherm. Res., 64: 233-267.

Saenz, R. 1971. Aparatos volcanicos y fuentes termales de Costa Rica. Inf. Tecn. Not. Geol. Direccion Geol. Min. Petrol., San José, Costa Rica, 41: 16 pp.

Sanford, W.E., L.F. Konikow, G.L. Rowe \& S.L. Brantley. 1995. Groundwater transport of crater-lake brine at Poás Volcano, Costa Rica. J. Volcanol. Geotherm. Res., 64: 269-293.

Schmid, M, M. Halbwachs, B., Wehrli \& A. Wüest. 2005. Weak mixing in Lake Kivu: new insights indicate increasing risk of uncontrolled gas eruption. Geochemistry, Geophysics, Geosystems, 6: 1-11, Q07009, doi:10.1029/2004GC00892.

Sigurdsson, H., J.D. Devince, F.M. Tchoua, T.S. Presser, M.K.W. Pringle \& W.C. Evans. 1987. Origin of the lethal gas burst from Lake Monoun, Cameroon. J. Volcanol. Geotherm. Res., 31: 1-16.

Simkin, T., L. Siebert, L. McClelland, D. Bridge, C. Newhall \& J.H. Latter. 1981. Volcanoes of the World. Washington, DC, Smithsonian Institution: $232 \mathrm{pp}$.

Symonds, R.B., T.M. Gerlach \& M.H. Reed. 2001. Magmatic gas scrubbing: implications for volcano monitoring. $J$. Volcanol. Geochim. Res., 108: 303-341.

Taran, Y.A., B.G. Pokrovsky \& A.D. Esikov. 1989. Deuterium and oxygen-18 in fumarolic steam and amphiboles from some Kamchatka volcanoes: "andesitic waters". Dokl. Akad. Nauk SSSR, 304: 440-443.

Tassi, F., F. Bergamaschi, O. Vaselli, E. Fernandez \& E. Duarte. 2003a. Crater lakes of Costa Rica: a geochemical survey. Proc. $8^{\text {th }}$ IAVCEI Field Workshop on "Volcanic Gases", 26 March - 1 April, 2003, Nicaragua-Costa Rica: 77-79.

Received: December 2008

Accepted: March 2009
Tassi, F., O. Vaselli, N. Pavanelli, B. Capaccioni, E. Duarte \& E. Fernandez. 2003b. Geochemical features of fluid discharges at Irazú volcano, Costa Rica. Proc. 3th "City on Volcanoes" Congress, Hilo, Hawaii, USA, 14-18 July.

Tassi, F., G. Montegrossi \& O. Vaselli. 2004a. Metodologie di campionamento ed analisi di fasi gassose. Int. Rep. CNRIGG, Florence, $\mathrm{n}^{\circ}$ 1/2003: $16 \mathrm{pp}$.

Tassi, F., O. Vaselli, B. Capaccioni, C. Giolito, E. Duarte, E. Fernandez, A. Minissale \& G. Magro. 2005. The hydrothermal-volcanic system of Rincón de la Vieja volcano (Costa Rica): a combined (inorganic and organic) geochemical approach to understanding the origin of the fluid discharges and its possible application to volcanic surveillance. J. Volcanol. Geothem. Res., 148: 315-333.

Tassi, F., O. Vaselli, L. Giannini, D. Tedesco, A. Nencetti, G. Montegrossi \& M.M. Yalire. 2004b. A low-cost and effective method to collect water and gas samples from stratified crater lakes: the $485 \mathrm{~m}$ deep lake Kivu (DRC). Proc. IAVCEI Gen. Ass., Puchon, Chile, 14-19 November.

Tassi, F., O. Vaselli, D. Tedesco, G. Montegrossi, T. Darrah, E. Cuoco, M.Y. Mapendano, R. Poreda \& A. Delgado Huertas. 2009. Water and gas chemistry at Lake Kivu (DRC): geochemical evidence of vertical and horizontal heterogeneities in a multi-basin structure. Geochem. Geophys. Geosyst., 10, Q02005, doi:10.1029/2008GC002191.

Varekamp, J.C., A.P. Ouimette, S.W. Herman, K.S. Flynn, A. Bermudez \& D. Delpino. (2009). Naturally acid waters from Copahue Volcano, Argentina. Appl. Geochem.: (in press).

Varekamp, J.C., G.B. Pasternack \& G.L. Rowe. 2000. Volcanic lake systematics II. Chemical constraints. J. Volcanol. Geotherm. Res., 97: 161-179.

Vaselli, O., F. Tassi, G. Montegrossi, E. Duarte \& E. Fernandez. 2003a. Poás volcano (Costa Rica): fumarole migration and chemical variation from 1998 to 2001. Special Memory of the Geol. Soc. of London (UK), 213: 247-262.

Vaselli, O., F. Tassi, C. Giolito, M. Martinez, E. Fernandez, E. Duarte, J. Barquero, B. Capaccioni \& M. Van Bergen. 2003b. Geochemistry and fluid circulation at the Tenorio volcanic complex. Proc. Geoitalia 2003, $4^{\text {th }}$ Italian Forum of the Earth Sciences (FIST), 16-18 September, Bellaria (Italy): 399-400 pp.

Vaselli, O., F. Tassi, G. Montegrossi, B. Capaccioni \& L. Giannini. 2006. Sampling and analysis of fumarolic gases. Acta Vulcanol., 1-2: 65-76. 